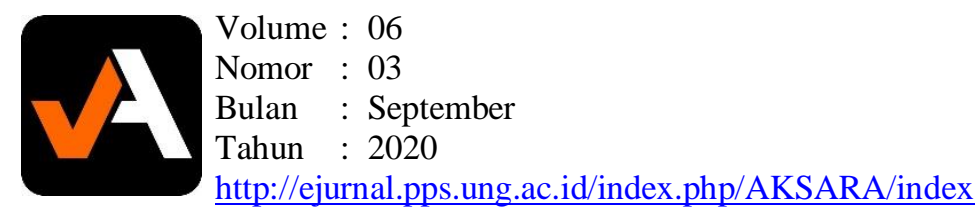

\title{
Meningkatkan Kemampuan Guru- Gurudalam Pelaksanaan Bimbingan Belajar Melalui Teknik Pendampingan Di SMP Negeri 1 Ponelo Kepulauan
}

\author{
Imran Atute \\ Dinas Pendidikan dan Kebudayaan \\ Kabupaten Gorontalo Utara
}

Received: 12 Januari 2020; Revised: 26 Februari 2020; Accepted: 28 April 2020

DOI: http://dx.doi.org/10.379 05/aksara.6.3.377-386.2020

\begin{abstract}
ABSTRAK
Berdasarkan kegiatan refleksi dan umpan balik yang dilakukan antara guru dan kepala sekolah disepakati untuk tidak melanjutkan penelitian ke siklus III karena guru pada dasarnya telah dapat melakukan aktivitas pendampingan sesuai dengan kesepakatan dan telah berimplikasi pada peningkatan kemampuan guru dalam untuk pelaksanaan bimbingan belajar terhadap siswa.Berdasarkan tindakan yang dilaksanakan selama penelitian jelas menunjukkan bahwa terjadi peningkatan kemampuan guru dalam melaksanakan kegiatan bimbingan belajar setelah dilaksanakan penelitian tindakan sekolah melalui 2 siklus dengan teknik pendampingan. Dengan temuan ini maka teknik pendampingan seyogyanya dijadikan sebagai rujukan dalam proses peningkatan kemampuan guru dalam melakukan bimbingan belajar terhadap siswa. Teknik análisis data yang digunakan dalam penelitian ini adalah dengan menjabarkan secara rinci perencanaan, pelaksanaan, observasi serta hasil pelaksanaan tindakan setiap siklus sehingga diperoleh gambaran yang jelas tentang hasil penelitian.
\end{abstract}

Kata Kunci: Bimbingan Belajar, dan Teknik Pendampingan

\section{PENDAHULUAN}

Pembelajaran merupakan proses dinamis yang dilakukan untuk mengembangkan potensi peserta didik secara optimal. Suatu pembelajaran akan bisa berjalan dan berhasil secara baik, manakala guru mampu mengubah diri peserta didik dalam arti yang luas serta mampu menumbuh kembangkan kesadaran peserta didik belajar, sehingga pengalaman yang diperoleh peserta didik selama ia terlibat di dalam proses pembelajaran itu, dapat dirasakan manfaatnya secara langsung bagi perkembangan pribadinya. Guru sebagai pengendali, pemimpin dan pengarah pada proses pembelajaran, sebagai pengelola pembelajaran merupakan pihak yang memiliki tugas, tanggung jawab dan inisiatif pembelajaran. Di sisi lain siswa sebagai yang terlibat langsung, perlu dituntut keaktifannya dalam proses pembelajaran. Agar proses pembelajaran bisa berjalan lancar, teratur dan terhindar dari beberapa hambatan, maka seorang guru harus mengerti, memahami, dan menghayati berbagai prinsip pembelajaran sekaligus mengaplikasikannya dalam proses pembelajaran. Dengan pemahaman serta wawasan yang memadai tentang pembelajaran maka guru dapat membimbing siswa belajar dengan optimal. Namun kondisi yang ada menunjukkan 


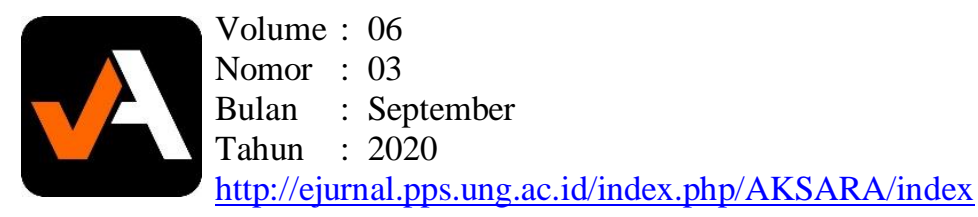

bahwa tidak semua siswa memiliki tingkat kemampuan belajar yang baik meskipun dibimbing atau dibina oleh guru. Banyak siswa yang tidak dapat belajar dengan baik bahkan tidak dapat menguasai dengan tuntas materi yang diajarkan. Siswa ini pada umumnya tidak memahami penjelasan guru serta tidak dapat menerapkan konsep pembelajaran yang diterimanya. Hal ini menunjukkan perlunya layanan bimbingan belajar sebagai usaha untuk membantu menemukan siswa yang membutuhkan bimbingan belajar. Keberadaan bimbingan belajar yang diberikan guru memegang peran yang sangat penting untuk meningkatkan kemampuan anak dalam memahami materi yang diajarkan. Dimana dengan bimbingan belajar yang baik diharapkan siswa akan memiliki kebiasaan belajar yang baik.

Langkah-langkah bimbingan belajar yang dilakukan di atas diharapkan mampu mengatasi masalah belajar yang dihadapi siswa serta diharapkan mampu membangun kebisaan belajar yang positif. Kebiasaan belajar positif yaitu tercermin dari perilaku siswa untuk belajar dengan rutin sehingga dapat memahami materi yang diajarkan guru. Berdasarkan pengamatan di lapangan menunjukkan bahwa tingkat kemampuan guru dalam melakukan kegiatan bimbingan belajar kurang optimal. Hal ini tercermin dari rendahnya kemampuan dan wawasan guru dalam melakukan prosedur untuk membantu siswa melalui kegiatan bimbingan belajar. Kondisi riil menunjukkan bahwa dari 6 komponen kemampuan yang diharapkan dapat dilakukan guru terdapat 4 komponen (66.67\%) yang belum dapat dilakukan dengan baik. Komponen tersebiut yaitu: a) komponen kemampuan guru dalam melakukan prognosis, b) komponen kemampuan guru dalam melakukan remedial atau referal (alih tangan kasus) dan c) komponen kemampuan guru dalam melakukan evaluasi dan follow up. Terkait permasalahan tersebut maka selaku kepala sekolah akan melakukan perbaikan dan peningkatan terhadap kemampuan guru dalam melakukan kegiatan bimbingan belajar. Teknik yang dilakukan yaitu dengan menggunakan teknik pendampingan. Teknik pendampingan pada dasarnya merupakan teknik yang dilakukan dengan cara mendampingi guru yang melakukan kegiatan pembimbingan kepada siswa khususnya terkait dengan kegiatan bimbingan belajar. Dalam prosesnya kegiatan pendampingan ini dilakukan secara informal sehingga guru tidak merasa diawasi dalam proses pemberian bimbingan belajar kepada siswa. Dengan teknik ini maka guru akan lebih leluasa dalam melakukan kegiatan pembimbingan sehingga kegiatan bimbingan akan mencapai hasil yang diharapkan.

\section{KAJIAN TEORETIS DAN HIPOTESIS TINDAKAN Hakikat Bimbingan Belajar}

Secara konsepsional layanan bimbingan diberikan kepada siswa agar mereka mampu mengatasi berbagai permasalahan yang dihadapi dalam hidupnya. Nurihsan (2005:27-28) mengemukakan bahwa layanan bimbingan yang diberikan kepada siswa bertujuan untuk membantu peserta didik mengembangkan perilaku efektif dan keterampilan-keterampilan hidupnya yang mengacu pada tugas -tugas perkembangan peserta didik. Tugas-tugas perkembangan peserta didik tersebut adalah: 1) mencapai perkembangan diri sebagai remaja yang beriman dan bertaqwa kepada Tuhan Yang Maha Esa, 2) mempersiapkan diri, menerima dan bersikap positif serta dinamis 


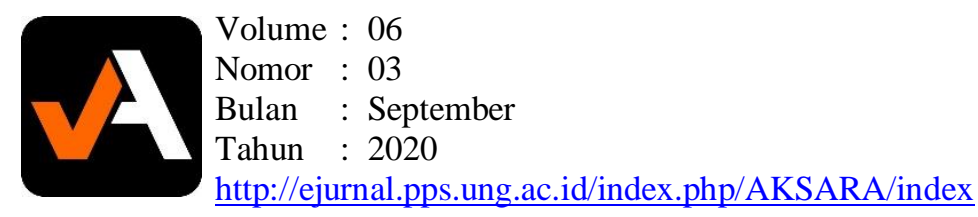

terhadap perubahan fisik dan psikhis yang terjadi pada diri sendiri untuk kehidupan yang sehat, 3) mencapai pola hubungan yang baik dengan teman sebaya dalam peranannya sebagai pria dan wanita, 4) memantapkan nilai dan cara bertingkah laku yang dapat diterima dalam kehidupan sosial yang lebih luas, 5) mengenal kemampuan, bakat, minat serta arah kecenderungan karir dan apresiasi seni, 6) mengembangkan pengetahuan dan keterampilan sesuai dengan kebutuhannya untuk mengikuti dan melanjutkan pelajaran dan/atau mempersipkan karir serta berperan dalam kehidupan masyarakat, 7) mengenal gambaran dan mengembangkan sikap tentang kehidupan mandiri secara emosional, sosial dan ekonomi, 8) mengenal sistem etika dan nilai-nilai bagi pedoman hidup sebagai pribadi, anggota dan minat manusia.

\section{Hakikat Teknik Pendampingan}

Salah satu satu teknik yang dapat digunakan untuk meningkatkan kemampuan guru dalam pelaksanaan pembelajaran yaitu dengan melakukan kegiatan pendampingan. Waliman, dkk. (2001:1) mengemukakan bahwa pendampingan adalah kegiatan yang difokuskan pada perbaikan pembelajaran melalui siklus yang sistematis mulai dari tahap perencanaan, pengamatan dan analisis yang intesif terhadap penampilan pembelajarannya dengan tujuan untuk memperbaiki proses pembelajaran.

Taufiq (2007:2) mengemukakan beberapa alasan mengapa pendampingan diperlukan, diantaranya:

a) Tidak ada balikan dari orang yang kompeten sejauhmana praktik profesional telah memenuhi standar kompetensi dan kode etik

b) Ketinggalan iptek dalam proses pembelajaran

c) Kehilangan identitas profesi

d) Kejenuhan profesional (bornout)

e) Pelanggaran kode etik yang akut

f) Mengulang kekeliruan secara masif

g) Erosi pengetahuan yang sudah didapat dari pendidikan prajabatan (PT)

h) Siswa dirugikan, tidak mendapatkan layanan sebagaimana mestinya

i) Rendahnya apresiasi dan kepercayaan masyarakat dan pemberi pekerjaan Secara umum tujuan pendampingan untuk:

1) Menciptakan kesadaran guru tentang tanggung jawabnya terhadap pelaksanaan kualitas proses pembelajaran.

2) Membantu guru untuk senantiasa memperbaiki dan meningkatkan kualitas proses pembelajaran.

3) Membantu guru untuk mengidentifikasi dan menganalisis masalah yang muncul dalam proses pembelajaran

4) Membantu guru untuk dapat menemukan cara pemecahan maslah yang ditemukan dalam proses pembelajaran

5) Membantu guru untuk mengembangkan sikap positif dalam mengembangkan diri secara berkelanjutan.

Waliman, dkk. (2001:1) mengemukakan bahwa kegiatan pendampingan memiliki karakteristik sebagai berikut:

1) Perbaikan dalam pembelajaran mengharuskan guru mempelajari keterampilan intelektual dan bertingkah laku berdasarkan keterampilan tersebut. 


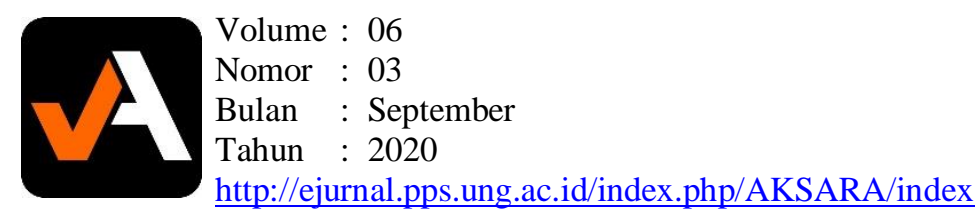

2) Fungsi utama pendamping adalah menginformasikan beberapa keterampilan, seperti: (1) keterampilan menganalisis proses pembelajaran berdasarkan hasil pengamatan, (2) keterampilan mengembangkan kurikulum, terutama bahan pembelajaran, (3) keterampilan dalam proses pembelajaran.

3) Fokus pendampingan adalah: (1) perbaikan proses pembelajaran, (2) keterampilan penampilan pembelajaran yang memiliki arti bagi keberhasilan mencapai tujuan pembelajaran dan memungkinkan untuk dilaksanakan, dan (3) didasarkan atas kesepakatan bersama dan pengalaman masa lampau.

\section{Peningkatan Kemampuan Guru Dalam Pelaksanaan Bimbingan Belajar Melalui Teknik Pendampingan}

Bimbingan belajar yang efektif merupakan hal yang sangat penting dalam, usaha memperbaiki dan meningkatkan kebiasaan belajar siswa. Bimbingan belajar pada dasarnya merupakan layanan bimbingan yang diberikan kepada siswa bertujuan untuk membantu peserta didik mengembangkan perilaku efektif dan keterampilanketerampilan hidupnya yang mengacu pada tugas -tugas perkembangan peserta didik.

Keberadaan bimbingan belajar ini sangat diharapkan sebagai wahana penyadaran kepada siswa tentang pentingnya belajar sehingga hal ini diharapkan menjadi pola hidup anak. Dalam konteks ini dengan bimbingan belajar maka anak diharapkan memiliki kesadaran yang tinggi untuk belajar sehingga dapat mempengaruhi kebiasaan belajarnya.

Secara konseptual kebiasaan belajar merupakan segala bentuk perilaku siswa yang ditujukan secara ajeg dari waktu-kewaktu dalam rangka pelaksanaan studi di Sekolah. Perlu diperhatikan bahwa kebiasaan belajar tidaklah sama dengan ketrampilan belajar. kebiasaan belajar adalah perilaku belajar seseorang dari waktu kewaktu dengan cara yang sama, sedang ketrampilan belajar adalah suatu sistem, metode, teknik yang telah dikuasai untuk melakukan studi. Kebiasaan belajar bukan merupakan bakat alamiah yang berasal dari faktor bawaan, tetapi merupakan perilaku yang dipelajari dengan secara sengaja dan sadar selama beberapa waktu. Karena diulang sepanjang waktu, berbagai perilaku itu begitu terbiasakan sehingga akhirnya terlaksana secara spontan tanpa memerlukan pikiran sadar sebagai tanggapan otomatis terhadap sesuatu proses belajar. Jika dicermati bahwa pembentukan kebiasaan belajar bisa dipengaruhi oleh imitasi dan sugesti. kebiasaan belajar yang baik dapat terbentuk karena lingkungan tempat peserta didik belajar merupakan lingkungan yang sudah terbiasa melakukan aktivitas belajar secara teratur. Kebiasaan ini bisa terbentuk secara tidak sadar sejak kecil melalui imitasi dari keluarga. Diantara cara membentuk kebiasaan belajar adalah dengan cara berbuat suatu aktivitas belajar walaupun mengalami kesulitan secara terus menerus. Ketika kegiatan ini diulang terus menerus maka akan membentuk tipe belajar yang dikehendaki. Maka terbentuklah suatu kebiasaan belajar sehingga merasa seakan-akan kurang tepat jika melakukan kegiatan lain.

\section{METODE PENELITIAN}

Penelitian ini dilaksanakan di SMP Negeri 1 Ponelo Kepulauan, Kabupaten GorontaloUtara, provinsi Gorontalo. Penelitian ini melibatkan semua guru mata 


$$
\begin{aligned}
& \text { Volume : } 06 \\
& \text { Nomor : } 03 \\
& \text { Bulan : September } \\
& \text { Tahun : } 2020 \\
& \text { http://ejurnal.pps.ung.ac.id/index.php/AKSARA/index }
\end{aligned}
$$

pelajaran yang berada di sekolah tersebut.Penelitian dilaksanakan selama 3 (tiga) bulan yaitu dari bulan Januari2020 sampai dengan bulan Maret 2020.

Subjek dalam penelitian ini adalah Guru- Guru di SMP Negeri 1 Ponelo Kepulauan, Kabupaten Gorontalo Utara. Penelitian dilaksanakan mengingat bahwa kemampuan guru dalam pelaksanaan bimbingan belajar terhadap siswa belum optimal. Oleh karenanya peneliti memandang bahwa kemampuan guru dalam pelaksanaan bimbingan belajar terhadap siswa perlu ditingkatkan melalui teknik pendampingan. Teknik análisis data yang digunakan dalam penelitian ini adalah dengan menjabarkan secara rinci perencanaan, pelaksanaan, observasi serta hasil pelaksanaan tindakan setiap siklus sehingga diperoleh gambaran yang jelas tentang hasil penelitian.

\section{HASIL PENELITIAN DAN PEMBAHASAN}

\section{Hasil Penelitian}

Sebelum peneliti melaksanakan kegiatan penelitian maka terlebih dahulu dilakukan kegiatan observasi awal untuk untuk melihat kondisi riil tentang kemampuan guru dalam pelaksanaan bimbingan belajar terhadap siswa. Hasil observasi terkait kemampuan guru dalam pelaksanaan bimbingan belajar terhadap siswa pada observasi awal ditampilkan pada tabel di bawah ini:

Tabel 1. Kemampuan Guru-guru di SMP Negeri 1 Ponelo Kepulauan, dalam Pelaksanaan bimbingan belajar Tahap Observasi Awal

\begin{tabular}{|l|c|c|c|}
\hline \multicolumn{1}{|c|}{ Kriteria Aspek yang dinilai } & Baik & Cukup & $\begin{array}{c}\text { Kurang } \\
\text { Baik }\end{array}$ \\
\hline $\begin{array}{l}\text { Kemampuan guru mengidentifikasi } \\
\text { kasus }\end{array}$ & $\sqrt{ }$ & - & - \\
\hline $\begin{array}{l}\text { Kemampuan guru melakukan } \\
\text { identifikasi masalah }\end{array}$ & $\sqrt{ }$ & - & - \\
\hline $\begin{array}{l}\text { Kemampuan guru dalam melakukan } \\
\text { diagnosis }\end{array}$ & - & $\sqrt{ }$ & - \\
\hline $\begin{array}{l}\text { Kemampuan guru dalam melakukan } \\
\text { prognosis }\end{array}$ & - & - & $\sqrt{ }$ \\
\hline $\begin{array}{l}\text { Kemampuan guru dalam melakukan } \\
\text { remedial atau referal (Alih Tangan }\end{array}$ & - & - & $\sqrt{ }$ \\
\hline $\begin{array}{l}\text { Kasus) } \\
\text { Kemampuan guru dalam melakukan }\end{array}$ & - & - & 3 \\
\hline Jumlah & 2 & 1 & $50.00 \%$ \\
\hline
\end{tabular}

Keterangan:

\section{Baik}

Skor $85-100$

$$
\text { Cukup }
$$

Skor 60-84
Kurang Baik

Skor $<59$

Tabel 1 di atas menunjukkan bahwa kemampuan guru dalam pelaksanaan bimbingan belajar terhadap siswa sangat rendah hal ini ditunjukkan dengan rendahnya kemampuan guru dalam menguasai komponen pelaksanaan bimbingan belajar. Dari 6 


$$
\begin{aligned}
& \text { Volume : } 06 \\
& \text { Nomor : } 03 \\
& \text { Bulan : September } \\
& \text { Tahun : } 2020 \\
& \text { http://ejurnal.pps.ung.ac.id/index.php/AKSARA/index }
\end{aligned}
$$

komponen utama yang diharapkan dapat dikuasai guru ternyata hanya sebanyak 2 komponen (33.33\% yang dapat dikuasai guru dengan baik) yaitu:

kemampuan guru mengidentifikasi kasus, dan b) kemampuan guru melakukan identifikasi masalah.

Dari hasil observasi diperoleh persentase capaian kemampuan guru-guru dalam pelaksanaan bimbingan belajar terhadap siswa siklus I di tampilkan dalam tabel berikut:

Tabel 2. Kemampuan Guru-guru di SMP Negeri 1 Ponelo Kepulauan dalam Pelaksanaan bimbingan belajar terhadap siswa Pada Siklus I

\begin{tabular}{|l|c|c|c|}
\hline \multicolumn{1}{|c|}{ Kriteria Aspek yang dinilai } & Baik & Cukup & $\begin{array}{c}\text { Kurang } \\
\text { Baik }\end{array}$ \\
\hline $\begin{array}{l}\text { Kemampuan guru mengidentifikasi } \\
\text { kasus }\end{array}$ & $\sqrt{ }$ & - & - \\
\hline $\begin{array}{l}\text { Kemampuan guru melakukan } \\
\text { identifikasi masalah }\end{array}$ & $\sqrt{ }$ & - & - \\
\hline $\begin{array}{l}\text { Kemampuan guru dalam melakukan } \\
\text { diagnosis }\end{array}$ & $\sqrt{ }$ & - & - \\
\hline $\begin{array}{l}\text { Kemampuan guru dalam melakukan } \\
\text { prognosis }\end{array}$ & $\sqrt{ }$ & - & - \\
\hline $\begin{array}{l}\text { Kemampuan guru dalam melakukan } \\
\text { remedial atau referal (Alih Tangan }\end{array}$ & - & $\sqrt{ }$ & - \\
\hline $\begin{array}{l}\text { Kasus) } \\
\text { Kemampuan guru dalam melakukan }\end{array}$ & - & $\sqrt{ }$ & - \\
\hline Jumlah $\%$ & 4 & 2 & - \\
\hline
\end{tabular}

Keterangan:

Baik

Skor $85-100$
Cukup

Skor 60-84
Kurang Baik

Skor $<59$

Dari data hasil observasi selanjutnya dijadikan sebagai acuan bagi guru untuk dapat mengevaluasi dan merefleksi. Dengan demikian maka guru memiliki standar yang dapat digunakan untuk menilai tingkat kemampuannya dalam membelajarkan siswa dengan meningkatkan kemampuan guru dalam pelaksanaan bimbingan belajar terhadap siswa. Tabel 2 di atas menunjukkan bahwa kemampuan guru dalam pelaksanaan bimbingan belajar terhadap siswa mengalami peningkatan setelah guru melakukan kegiatan pendampingan terhadap Guru-Guru di SMP Negeri 1 Ponelo Kepulauan, Kabupaten GorontaloUtara. Hal ini ditunjukkan dengan meningkatnya kemampuan guru dalam menguasai komponen pelaksanaan bimbingan belajar. Dari 6 komponen utama yang diharapkan dapat dikuasai guru ternyata sebanyak 4 komponen (66.67\% yang dapat dikuasai guru dengan baik) yaitu a) kemampuan guru mengidentifikasi kasus, b) kemampuan guru melakukan identifikasi masalah, c) 


$$
\begin{aligned}
& \text { Volume : } 06 \\
& \text { Nomor : } 03 \\
& \text { Bulan : September } \\
& \text { Tahun : } 2020 \\
& \text { http://ejurnal.pps.ung.ac.id/index.php/AKSARA/index }
\end{aligned}
$$

kemampuan guru dalam melakukan diagnosis, dan d) kemampuan guru dalam melakukan prognosis.

Tabel 3. Kemampuan Guru-guru SMP Negeri 1 Ponelo Kepulauan, Kabupaten GorontaloUtara dalam Pelaksanaan bimbingan belajar terhadap siswa Pada Siklus I

\begin{tabular}{|l|c|c|c|}
\hline \multicolumn{1}{|c|}{ Kriteria Aspek yang dinilai } & Baik & Cukup & $\begin{array}{c}\text { Kurang } \\
\text { Baik }\end{array}$ \\
\hline $\begin{array}{l}\text { Kemampuan guru mengidentifikasi } \\
\text { kasus }\end{array}$ & $\sqrt{ }$ & - & - \\
\hline $\begin{array}{l}\text { Kemampuan guru melakukan } \\
\text { identifikasi masalah }\end{array}$ & $\sqrt{ }$ & - & - \\
\hline $\begin{array}{l}\text { Kemampuan guru dalam melakukan } \\
\text { diagnosis }\end{array}$ & $\sqrt{ }$ & - & - \\
\hline $\begin{array}{l}\text { Kemampuan guru dalam melakukan } \\
\text { prognosis }\end{array}$ & $\sqrt{ }$ & - & - \\
\hline $\begin{array}{l}\text { Kemampuan guru dalam melakukan } \\
\text { remedial atau referal (Alih Tangan } \\
\text { Kasus) }\end{array}$ & $\sqrt{ }$ & - & - \\
\hline $\begin{array}{l}\text { Kemampuan guru dalam melakukan } \\
\text { evaluasi dan follow up }\end{array}$ & $\sqrt{ }$ & - & - \\
\hline Jumlah & 6 & 0 & -0 \\
\hline
\end{tabular}

Keterangan:

Baik

Skor $85-100$
Cukup

Skor 60-84
Kurang Baik

Skor $<59$

Tabel 3 di atas menunjukkan bahwa kemampuan guru dalam pelaksanaan bimbingan belajar terhadap siswa mengalami peningkatan setelah guru melakukan kegiatan pendampingan terhadap Guru-Guru di SMP Negeri 1 Ponelo Kepulauan, Kabupaten GorontaloUtara. Hal ini ditunjukkan dengan meningkatnya kemampuan guru dalam menguasai komponen pelaksanaan bimbingan belajar. Dari 6 komponen utama yang diharapkan dapat dikuasai guru ternyata semuanya telah dapat dikuasai guru dengan baik. Penguasaan ini terjadi karena dalam proses pendampingan guru-guru kelas atas merasa diayomi oleh peneliti sebagai kepala sekolah dan mendapatkan bimbingan yang optimal sehingga penguasaan atas 6 kemampuan dalam pelaksanaan bimbingan belajar dapat dilakukan dengan baik.

\section{Pembahasan}

Bimbingan belajar merupakan salah satu kompetensi yang perlu dikuasai guru dalam melakukan kegiatan bimbingan terhadap siswa. Pelaksanaan kegiatan bimbingan perlu dilakukan dengan optimal

\section{$\underline{\text { Belajar }}$}

Binet (2007:1) mengemukakan bahwa secara umum Tujuan layanan bimbingan 


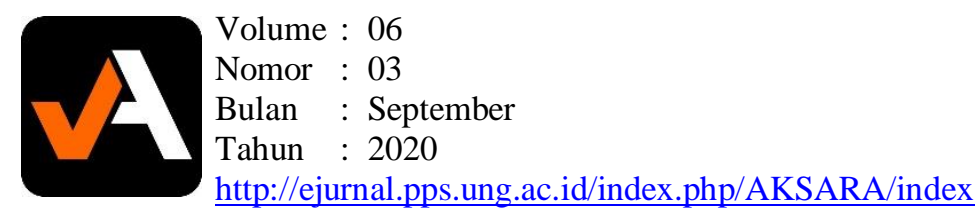

1. Merencanakan kegiatan penyelesaian studi, perkembangan karir serta kehidupan-nya di masa yang akan datang.

2. Mengembangkan seluruh potensi dan kekuatan yang dimiliki peserta didik secara optimal.

3. Menyesuaikan diri dengan lingkungan pendidikan, lingkungan masyarakat serta lingkungan kerjanya.

4. Mengatasi hambatan dan kesulitan yang dihadapi dalam studi, penyesuaian dengan lingkungan pendidikan, masyarakat, maupun lingkungan kerja.

Untuk mencapai tujuan-tujuan tersebut, mereka harus mendapatkan kesempatan untuk :

1. Mengenal dan memahami potensi, kekuatan, dan tugas-tugas perkembangannya.

2. Mengenal dan memahami potensi atau peluang yang ada di lingkungannya,

3. Mengenal dan menentukan tujuan dan rencana hidupnya serta rencana pencapaian tujuan tersebut

4. Memahami dan mengatasi kesulitan-kesulitan sendiri.

5. Menggunakan kemampuannya untuk kepentingan dirinya, kepentingan lembaga tempat bekerja dan masyarakat.

6. Menyesuaikan diri dengan keadaan dan tuntutan dari lingkungannya.

7. Mengembangkan segala potensi dan kekuatan yang dimilikinya secara optimal.

Berdasarkan hasil penelitian tindakan sekolah yang dilaksanakan selama 2 siklus di SMP Negeri 1 Ponelo Kepulauan, Kabupaten GorontaloUtara, diperoleh data hasil penelitian terkait peningkatan kemampuan guru-guru kelas atas dalam pelaksanaan bimbingan belajar terhadap siswa. Dari kegiatan siklus I menunjukkan bahwa kemampuan guru-guru dalam pelaksanaan bimbingan belajar terhadap siswa mengalami peningkatan dari hasil observasi sebelumnya. Dalam konteks ini guru telah dapat melaksanakan kegiatan bimbingan belajar terhadap siswa setelah kegiatan pendampingan dilakukan. Kondisi riil yang terjadi dari peningkatan kemampuan siswa dalam melakukan kegiatan bimbingan belajara antara lain ditunjukkan dengan beberapa hal sebagai berikut:

a. Pada langkah diagnosis guru telah mampu menemukan faktor-faktor penyebab atau yang melatarbelakangi timbulnya masalah siswa. Dalam konteks ini guru telah mampu mengidentfikadi faktor-faktor yang penyebab kegagalan belajar siswa, bisa dilihat dari segi input, proses, ataupun out put belajarnya.

b. Berdasarkan hasil identifikasi tersebut guru selanjutnya mengklasifikasinya ke dalam dua bagian faktor - faktor yang mungkin dapat menimbulkan kesulitan atau kegagalan belajar siswa, yaitu : (a) faktor internal; faktor yang besumber dari dalam diri siswa itu sendiri, seperti : kondisi jasmani dan kesehatan, kecerdasan, bakat, kepribadian, emosi, sikap serta kondisi-kondisi psikis lainnya; dan (b) faktor eksternal, seperti : lingkungan rumah, lingkungan sekolah termasuk didalamnya faktor guru dan lingkungan sosial dan sejenisnya. Dengan langkah ini maka proses diagnosis terhadap siswa berjalan dengan baik dan dapat diketahui permasalahan utama yang menghambat proses dan kegiatan belajar siswa. 


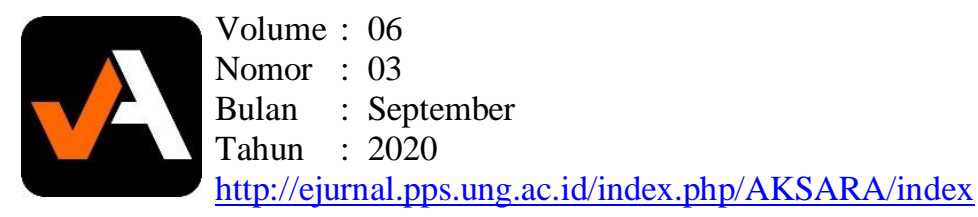

c. Pada tahap prognosis guru telah mampu memperkirakan apakah masalah yang dialami siswa masih mungkin untuk diatasi serta menentukan berbagai alternatif pemecahannya. Dalam konteks ini prediksi guru sangat tepat sehingga hal ini sangat membantu dalam melakukan interpreatasi terhadap kasus-kasus yang dihadapi siswa terkait hambatan belajarnya. Strategi yang dilakukan guru yaitu dengan cara mengintegrasikan dan menginterpretasikan hasil-hasil langkah kedua dan ketiga. Proses mengambil keputusan pada tahap ini seyogyanya terlebih dahulu dilaksanakan konferensi kasus, dengan melibatkan pihak-pihak yang kompeten untuk diminta bekerja sama menangani kasus - kasus yang dihadapi.

Dari hasil refleksi dan umpan balik yang dilakukan oleh guru para pengamat disimpulkan beberapa hal yang perlu diperbaiki dalam upaya meningkatkan kemampuan guru dalam pelaksanaan bimbingan belajar terhadap siswa sebagai berikut:

a. Masih terdapat dua komponen yang perlu ditingkatkan oleh guru-guru dalam pelaksanaan bimbingan belajar terhadap siswa.

b. Dalam proses pembimbingan belajar guru perlu melakukan analisis yang tajam terhadap berbagai hal yang menjadi penyebab masalah kesulitan belajar siswa sehingga menjadi dasar dalam penetapan strategi yang digunakan dalam pelaksanaan bimbingan belajar.

\section{SIMPULAN DAN SARAN}

\section{Simpulan}

Berdasarkan deskripsi hasil penelitian dan pembahasan, dapat disimpulkan bahwa:

1. Kemampuan guru dalam pelaksanaan bimbingan belajar terhadap siswa mengalami peningkatan setelah dikenai tindakan melalui II siklus.

2. Peningkatan kemampuan guru dalam dalam pelaksanaan bimbingan belajar terhadap siswa ditandai dengan penguasaan guru secara optimal terhadap 6 komponen yaitu a) kemampuan guru mengidentifikasi kasus, b) kemampuan guru melakukan identifikasi masalah, c) kemampuan guru dalam melakukan diagnosis, d) kemampuan guru dalam melakukan prognosis, e) kemampuan guru dalam melakukan remedial atau referal (alih tangan kasus), dan f) kemampuan guru dalam melakukan evaluasi dan follow up

\section{Saran}

Dari hasil penelitian tindakan kelas ini, maka dapat dikemukakan saran-saran sebagai berikut:

1. Perlu komitmen yang tinggi dari para guru untuk melakukan kegiatan bimbingan belajar sehingga mampu meningkatkan kompetensi siswa dalam pembelajaran

2. pendampingan bagi guru secara kontinu tentang prosedur dan mekanisme yang dapat dilakukan pelaksanaan bimbingan belajar terhadap siswa sehingga memutakhirkan kemampuan guru dalam proses pembelajaran

3. Perlu diadakan kegiatan penelitian lanjutan untuk menganalisis berbagai hal yang berkaitan dengan upaya untuk mengembangkan kompetensi guru dalam pelaksanaan bimbingan belajar terhadap siswa yang sesuai karakteristik siswa pada populasi yang lebih besar. 


\section{DAFTAR PUSTAKA}

Agus Taufiq. 2007. Pendampingan Bimbingan dan Konseling (Bahan Pelatihan BK di Cikole). Bandung.

Binet. 2010. Layanan Bimbingan Belajar. (Online) Tersedia dihttp://jaringanilmupengetahuan.blogspot.com/2010/04/tujuan-layananbimbingan-belajar.sadja.html

Iim Waliman, dkk. 2001. Pendampingan (Modul Manajemen Berbasis Sekolah). Bandung : Dinas Pendidikan Provinsi Jawa Barat

Joni, T. Raka. 2004. Pedoman Umum Alat Penilaian Kemampuan Guru. Jakarta: Dirjen Pendidikan Tinggi Depdikbud

Nasution. 2005. Pendidikan Guru Berdasarkan Pendekatan Kompetensi. Jakarta: PT. Bumi Aksara

Nurihsan Juntika Ahmad. 2005. Strategi Layanan Bimbingan dan Konseling. Jakarta: PT Rafika Aditama.

Nurihsan Juntika dan Yusuf Syamsu. 2007. Landasan Bimbingan dan Konseling. Bandung: Program Pasca Sarjana Universitas Pendidikan Indonesia dan PT Remaja Rosda Karya

Siagian. 2009. Administrasi Dan Supervisi Pendidikan, Bandung PT Remaja Rosda Karya

Sudradjat Akhmad. 2007. Kesulitan Belajar Siswa dan Bimbingan Belajar (Online) Tersedia di http/www.kes.rtti.,com.press.html

Sukmawati. 2009. Interaksi Belajar Mengaajar. Jakarta: Rineka Cipta 